\title{
METHODS OF FOREIGN LANGUAGE TEACHING IN THE MODERN SYSTEM OF HIGHER EDUCATION
}

The needs of modern society have led to the emergence of many new effective and interesting methods and approaches to teaching a foreign language, offering students an individual approach depending on the depth of their knowledge, needs, opportunities and time devoted to learning a language. The purpose of the research is to consider and analyze the main methods, techniques and technologies of teaching a foreign language in the modern system of higher education. To achieve this goal, the following items were used - the method of theoretical analysis of scientific and methodological works on problematic issues of methods of teaching pedagogy; generalization of ow-n pedagogical experience; methods of generalization, systematization for formulating the conclusions of scientific research. The choice of modern teaching methods is determined by the following criteria: creating a comfortable environment for students that meets their real interests, needs and desire to practically use a foreign language, with the stimulation of their speech, cognitive and creative abilities; the use of various forms of work that stimulate students' activity, independence, creativity; creating conditions under which the teacher is not a central figure; activating the personality, giving him a primary role in the learning process with active interaction with other participants. It is important to note that the choice of a certain method depends on the material that is offered for learning, the connection of the studied material with the previous and subsequent ones, the ratio of theoretical and practical elements in it, the level of students'general development and their preparation for the subject. An analysis of the spectrum of methods for learning a foreign language and their development made it possible to conclude that there is no universal methodology. The techniques, methods and approaches that are used have much in common; they differ in ways and forms, but have a common goal - to teach the recipient a foreign language.

Key words: method, techniques, approach, learning technology, communicative competence.

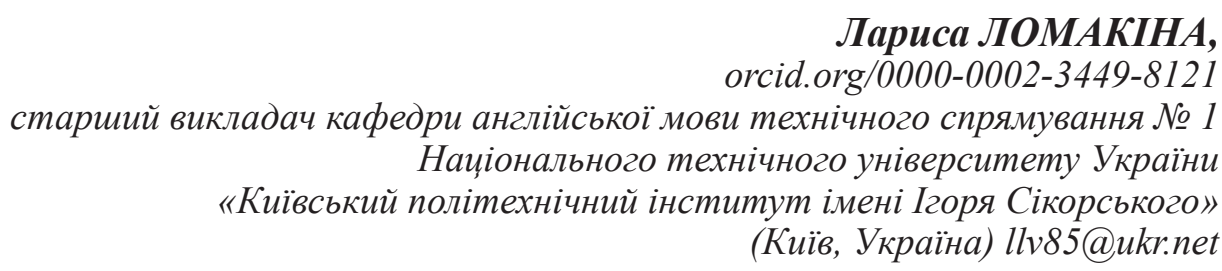

\section{МЕТОДИ НАВЧАННЯ ІНОЗЕМНОЇ МОВИ В СУЧАСНІЙ СИСТЕМІ ВИЩОЇ ОСВІТИ}

\begin{abstract}
Потреби сучасного суспільства зумовили появу безлічі нових ефективних і иікавих методів і підходів до навчання іноземної мови, пропонуючи студенту індивідуальний підхід залежно від необхідної глибини знань, потреб, можливостей і часу, присвяченого вивченню мови. Мета дослідження - розглянути та проаналізувати основні методи, прийоми і технологї̈ навчання іноземної мови в сучасній системі вищої освіти. Для досягнення поставленоі мети використовувались метод теоретичного аналізу науково-методичних праць із проблемних питань методики викладання педагогіки; методи узагальнення власного педагогічного досвіду, систематизації для формулювання висновків наукового дослідження. Вибір сучасних методів навчання визначається такими критеріями: створення комфортного для студентів середовища, щзо відповідає їхнім реальним інтересам і потребам, бажанню практично використовувати іноземну мову, зі стимулюванням мовленнєвих, пізнавальних та творчих здібностей особистості; використання різних форм роботи, щзо стимулюють студентську активність, самостійність, творчі здібності; активізація особистості з наданням їй основної ролі в процесі навчання при активній взаємодії з іншими учасниками; створення умов, за яких викладач не є иентральною фігурою. Важливо зазначити, щзо вибір методу залежить від матеріалу, який пропонується для вивчення, зв'язку вивченого матеріалу з попереднім і наступним, співвідношення в ньому елементів теоретичного і практичного характеру, рівня загального розвитку учнів та їх підготовки з предмета. Аналіз спектра методів вивчення іноземної мови та їх розвитку дав змогу зробити висновок, щзо універсальної методики не існує. Прийоми, методи і технології, які використовуються, мають багато спільного, відрізняються способами і формами, проте мають спільну мету - навчити рецииієнта іноземної мови.

Ключові слова: метод, прийом, технологія навчання, комунікативна компетениія.
\end{abstract}


Problem setting. The study of foreign languages in modern society is becoming an integral part of the professional growth of specialists in various fields. The quality of their speech training greatly depends on the successful solution of training issues. New conditions of professional training of future specialists in higher education establishments, which are caused by rapid technological development, and changes in approaches to teaching and learning, provide the effective implementation of educational programs, the simplification of student-teacher communication by introducing non-traditional methods that are characterized by flexibility of innovative learning technologies. Innovations in the process of learning a foreign language relate to various aspects of the educational process, including changes in the organization of space in classrooms, equipping classrooms with modern technology, as well as the use of new educational technologies both during classroom classes and during students' self-study. The use of computer technology significantly expands the learning opportunities available to both students and teachers, allows us to design and use a new generation of learning environment that is realistic, authentic and attractive.

The success of training largely depends on the teaching methodology of the teacher, his ability to use various innovative methods and techniques in teaching. Under such circumstances, the problem of choosing the most effective innovative methods and technologies in the modern system of higher professional education remains significant and relevant.

Analysis of recent research. Modern Ukrainian and foreign scientists are working on the search for innovative forms and methods of teaching, improving the conditions for mastering a foreign language by individualizing training, increasing the range of new technological teaching aids, and comprehensively using non-traditional forms of organizing the educational process in higher educational establishments. Numerous theoretical studies by N. Boriska, G. Kryukova, N. Ksenofontova, V. Feofilova, S. Nikolaieva, G. Podelets, V. Redko and others are devoted to the question of the methodology of teaching a foreign language. Proceedings of these scientists have shown that the system of non-traditional methods and techniques contributes to the more successful formation of foreign-language speech skills and habits. Problems of integration of classroom and independent extracurricular work of students with the use of information and communication technologies were considered in the works of D. Bodnenko, N. Bolyubash, A. Burmistrov, V. Hnezdilov, I. Ilin, E. Kostina, M. Koval, S. Shokaliuk, C. Christensen, M. Horn, H. Staker, C. Bonk, C. Graham, S. Khan, whose research has shown that blended learning does not require radical changes in the classical model, which forms important socio-cultural qualities of a person, but when it is used, the cognitive activity of students is activated and the qualities necessary for life and activity in the information society are formed (Podlasov, Matviichuk, Bryhinets, 2017). Such scientists as M. Danilov, B. Vsesviatskyi, I. Lerner, M. Skatkin, B. Yesipov, E. Golant, S. Perovskyi and others considered the problem of teaching methods. In modern didactics, there are a large number of teaching methods and techniques, but none of them can be recognized as universal.

The purpose of the research is to consider and analyze the main methods, techniques and technologies of teaching a foreign language in the modern system of higher education.

To achieve this goal, the following items were used - the method of theoretical analysis of scientific and methodological works on problematic issues of methods of teaching pedagogy; generalization of own pedagogical experience; methods of generalization, systematization for formulating the conclusions of scientific research.

Presentation of the main material. The learning process should not stand still; it should meet modern requirements and needs. As we live in the era of globalization, it is necessary to make the fullest and most effective use of the achievements of computer technology: they can speed up and facilitate the study of a particular discipline.

The available methods of ensuring the educational process are of sufficient quality and very effective. Teaching methods are understood as the methods of activity of the teacher and students, aimed at solving educational problems. In addition, the teaching method acts as a tool for the teacher's activities to fulfill the leadership function - to provide education (Aloshyna, 2012: 242-243).

The method is one of the main components of the training system, which helps to achieve the goals and objectives of training. In didactics and language teaching methods, there is a contradiction not only in the interpretation of the term "method", but also in the classification of teaching methods. The analysis of scientific research shows that the methodology does not have a clear definition of the term "teaching method". In the Ukrainian dictionary, the term «method» is interpreted as a technique or a system of techniques used in any field of activity (science, production, etc.). In our opinion, a teaching method is a system of interrelated actions of a teacher (teaching methods and techniques) and students aimed at achieving the learning goals. Technique is an element of a method. The elements of methods are not the sum of separate parts of the whole, but a system 
united by the logic of a didactic task. If a method is a mode of action that spans the entire path of its flow, then a technique is a separate step, an action, in the implementation of the method. The richer the arsenal of techniques in the structure of the method, the completer and more effective it is.

Each teaching method should perform not only educational, developmental functions, but also motivational and corrective (development of perception, thinking, imagination, memory, emotional-sensory sphere). Any academic discipline, except for the generally accepted teaching methods, has its own methods, due to the specifics of their content (Babanskyi, 1985: 154).

Techniques differ in the structure of methods, so each method can be represented as a set of methodological techniques. Itis necessary to distinguish between methods of mental activity (logical methods) - highlighting the main thing, analogy, concretization, comparison, etc., as well as methods of pedagogical work - problem solving, examples, grammatical analysis, etc. Logical techniques are the same for different methods. Only a systemic combination of techniques forms a specific teaching method, so the order in which they are used is important. The same techniques can be used in different teaching methods, but when combined with other techniques, they create a completely different teaching method. For example, the memorization technique is found both in reproductive methods and in methods of problem finding. But if in the first group of methods it dominates, then in the second it is a supplementary method, since it helps to remember the main results of problematic considerations. In addition, it should be noted that a method can become a technique and a technique can become a method. When a technique begins to perform the main training burden (helps to reveal the essence of a specific problem), it becomes a method. For example, correcting students' responses (as a technique) during a conversation can turn into a discussion level. Under this condition, this technique can become an independent teaching method (discussion). It is important to emphasize that the dialectic of the transition from method to technique or vice versa comes from the logic of the educational process, the existence of contradictory aspects between the purpose and the means of its achievement, several elements of cognitive activity (Kondrashova, Permiakov, 2006: 136).

The role of the method in the methodology of teaching foreign languages has always been defined as dominant. The methods of teaching a foreign language use such methods as grammatical translation, consciously contrasting, cognitive, direct, audio-lingual, structural, audiovisual, reading, transformation, etc. they are fundamentally different in content, justification, order and dosage of its introduction depending on the types of educational units and exercises (Viatiutnev, 1984: 12).

In the opinion of the overwhelming majority of linguodidactuals, the choice of one method or another depends on the material offered for study, the connection of the material being studied with the previous and subsequent ones, the ratio of theoretical and practical elements in it, the general level of development of students and their preparation for the subject.

The choice of modern teaching methods is determined by the following criteria: creating an environment in which the student feels comfortable and free, stimulating his interests, developing a desire to practically use a foreign language, which will contribute to real success; fascination of the student, attracting emotions, experiences for learning that correspond to his real needs, stimulate the speech, cognitive and creative abilities of the individual; enhancing the personality, giving him a primary role in the learning process with active interaction with other participants; creating a situation in which the teacher is not the central figure; teach the student to work on the language independently at the level of physical, intellectual and emotional abilities, which will help to ensure differentiation and individualization in the learning process; the use of various forms of work that stimulate the student's activity, independence, creativity.

In the scientific literature, methods of teaching a foreign language are divided depending on which aspect of the language prevails in teaching, namely: grammatical or lexical (Artemeva, 2005). According to the role played by the native language and translation in teaching foreign languages, methods are divided into translational and unhindered or direct. According to the purpose, two methods are distinguished - the oral method and the reading method, according to the techniques - audiovisual and visual, according to the principleoforganization-thetraditional and programmed teaching method.

At this stage of the development of methodological science, the main methods of teaching foreign languages are communicative and constructivist.

The educational purpose of the communicative method is to master communicative competence. Learning is not carried out through grammar, but is directed by communicative intentions. The student finds himself in the center of learning. Students learn communication in the process of communication itself. Accordingly, all exercises and tasks should be communicatively justified by the lack of information, choice and reaction. The advantages of this method include the improvement of students' oral skills, overcoming the fear of mistakes. The disadvantages of the method are the lack of due attention to the quality of 
language and the fact that communicative competence reaches its limits quite quickly.

The constructivist method is based on the actual active training of students. The teacher's task is not to teach, but to contribute to the educational process. The lesson appears to be action-oriented. The advantage of the method is to prepare students for real life, real life situations. The shortcomings of the method at the present stage have not yet clearly shown. An example of a constructivist method is project-based training.

The methodology distinguishes between traditional and alternative (non-traditional) teaching methods. Among the traditional methods that are most often used in the process of teaching students, we can highlight conversations. The most effective methods that contribute to the improvement of students' professional dialogical speech are such forms of educational activities as: conferences, presentations, and excursions, conducting classes in the conditions of real professional training.

Traditional methods of teaching a foreign language involve the assimilation of knowledge in artificial situations, as a result of which the future graduate does not see the connection of the studied subject with his future professional activity. The most effective means of developing the thinking of future graduates is simulation modeling. Such an approach to training ensures the imitation of the elements of professional activity, its typical and essential features. Its use in foreign language classes makes it possible to form communication skills; develops the habit of self-control, contributes to the real preparation of students for future activities and life in society; helps to make foreign language classes more lively, interesting, meaningful, give students the opportunity to express their thoughts, feelings, assessments, that is, to think in a foreign language. The following techniques can be used to improve the professional orientation of learning a foreign language: communication - a dialogue about professional information in a foreign language, analysis of social and professional situations, performing of creative tasks on specialized content, game situations, role-playing games, quizzes.

The concept of alternative methods refers to a number of different approaches, techniques, methods of speech transmission. There are such alternative methods as the method of Total Physical Response, the suggestive method, drama-teaching method, the Silent Way method, group teaching method. Innovative learning methods include: training with computer support (Call), scenario method (Storyline Method), simulation method, carousel method, method of training in stations, group puzzle method, role-playing method, Case Stage method (work on problem situations, students consider the problem, analyze the situation, represent their ideas and solving problems during the discussion).

Non-traditional teaching methods contribute to the immersion of students in professional activity, which are able to activate professional interest and allow them to express themselves, to demonstrate the skill of dialogue interaction. The essence of interactive technologies lies in the fact that learning takes place through the interaction of all learners, and this is especially characteristic of the practice of teaching a foreign language. The methods of interactive learning include role-playing / business games and situational tasks "brainstorming", "casemethod", thematic discussion, "round table" method, seminars-disputes, etc.

However, the use of online technologies in education has divided the learning environment into classroom learning environment and distance learning environment, which remain largely separate, as they rely on different means of presenting information and are aimed at meeting the needs of different audiences. At the same time, the implementation of modern information technologies and the emergence of new approaches to the learning process allows teachers to introduce the best methodology for the development and acquisition of students' communicative competence - blended learning, which successfully combines online learning with the presence of a teacher in a classroom format (Shchehlova, 2016).

Blended learning is an educational concept that allows the use of traditional and innovative teaching methods. The student attends "live" classes in the classroom, but at the same time widely uses information and communication technologies (ICT) in their training through information processing devices: a personal computer, an electronic notebook, mobile devices, etc.

In recent years, many new innovative methods have appeared in the field of teaching foreign languages.

Community language learning / Counseling learning («community» method, «advisor» method). The method is based on the humanistic approach to teaching and the psychological theory of the "advisor", the essence of which is that people need the help of a counselor-psychologist. The main method of teaching is translation from the native language into a foreign one. The learning process is structured so that students discuss the topic of conversation, communicate in a foreign language, and the teacher only observes from the outside and suggests equivalents in a foreign language. The disadvantage of this method is the lack of programs and a specific training plan, which prevents the widespread use of this method in higher educational establishments (Kashyna, 2006).

Suggestopedia method. A distinctive feature of this method is the disclosure of memory reserves due 
to specially organized classes, increasing of students' intellectual activity, the use of suggestion and relaxation. The main means of activating the reserve capabilities of a person are: the authority of the teacher; infantilization (the group creates favorable conditions for learning and assimilation of new material, role-playing games, music are used); two-planarity (the teacher and students use gestures, facial expressions to influence the interlocutor) intonation, rhythm (text material is presented by the teacher in a certain rhythm, accompanied by specially selected music. Music and rhythm should contribute to relaxation and more effective perception of the material.

The Silent Way metod. The essence of the method lies in the fact that the initiative in foreign language classes comes from the students, and the teacher should speak less. Learning in silence, as opposed to repetition and reproduction by the teacher, becomes a technique that promotes students' mental activity and concentration. The application of this method has a certain framework, as it involves students' high motivation and interest, which is not always possible to achieve in higher educational establishments.

Consciousness-raising approach. This method is based on understanding the form of a speech phenomenon - lexical and grammatical - and it is based on the data of contractual linguistics and the inductive way of mastering the language. The approach was developed in relation to teaching grammar: mastering grammatical skills was seen as a gradual awareness of form.

Task based learning. The method of communicative tasks is the solution of a number of communicative tasks offered by the teacher. By solving these tasks, communicating with each other, students perform speech actions, trying to find the right ways to solve the communicative problem. Thanks to this, there is an immersion in the speech environment and students begin to communicate in a foreign language for practical purpose. This method is especially effective for group teaching.

Neuro-linguistic programming. The term neurolinguistic programming can be explained as follows: the root "neuro" indicates that it is necessary to know and understand the "language of the brain" - those neurological processes that are responsible for storing, processing and transmitting information, the root "linguistic" emphasizes the importance of language in describing mechanisms of thinking and behavior, as well as in the organization of communication processes. One of the main ideas of this method is situational and behavioral modeling. This direction in the methodology of teaching a foreign language allows you to successfully reveal and activate the reserve capabilities of a person during the process of immersion in a foreign language space.
The method of teaching a language using information and communication technologies. The use of ICT in teaching foreign languages helps to intensify and individualize learning, contributes to increasing interest in the subject and correctness.

It is necessary to focus on the most effective methods: Smartphone-Lead-in in which, even before starting work on a new topic, students are invited to take photos and videos on a given topic using smart phones during the week; students send the results by e-mail, the teacher chooses the most interesting messages for discussion; Internet-Browse, when students search for text on a given topic on the Internet, which they must filter, check and present in the classroom; the highest rating is given to those posts that are not based on Wikipedia articles and the first three articles in the Google search engine; Video Maker, where students in small groups create videos (short presentations, animation, staging) on the topic, defining their own ways of achieving goals; Google-Maps and StreetviewExcursions: provide virtual acquaintance and study of new areas and territories, acquaintance with the architectural heritage of different cultures and eras; PowerPoint Presentations: taking into account the importance of computer presentations in professional life, students are actively involved in presenting short abstracts in graphic form on slides; Digital Stations: In the classroom we place tablets, laptops or smartphones in different places, where we offer students (in headphones) to listen to Podcast, watch a short video or listen to audio recordings and independently expand the proposed content of the information from the Internet; Barometer of Social Networks' Mood: Students focus on messages in their tape on a given topic; collected (anonymous) information is represented and discussed in the group, provides impulses to students to form and develop metacognitive strategies by broadcasting information obtained mainly in their native language, by means of a foreign language; e-jigsaw: provides training in collaboration with active use of ICTs for information retrieval. At the first stage, expert groups are formed whose task is to study individual aspects of the proposed problem using Internet information sources. At the second stage, one participant from each expert group creates main groups, the purpose of which is to integrate all the information received from the experts into a single resource. This method, adapted to the use of ICT, optimizes the level of information retrieval, its comprehension, expansion and, as a result, application; Cinquian Writing: offers independent writing of short five-line poems in which students synthesize the studied material, develop critical thinking; using hyperlinks, have the opportunity to enhance the content of the poem with information from the Internet, which visualizes 
the text of the poem, on the one hand, and enhances the motivational aspect, on the other.

Conclusions and prospects for further research. The modern educational environment contains three main components: traditional, independent and online learning. Traditional teaching is represented by classic classroom sessions or webinars, where the teacher works directly with a group of students. Self-study assumes independent work of students using various electronic resources. Online learning involves the work of a teacher and students live.

An analysis of the spectrum of methods for learning a foreign language and their development made it possible to conclude that there is no universal methodology. The techniques and methods that are used have much in common; they differ in ways and forms, but have a common goal - to teach the recipient a foreign language.
The choice of this or that method depends on the material that is offered for study, the connection of the studied material with the previous and subsequent ones, the ratio of theoretical and practical elements in it, the level of students' general development and their preparation for the subject.

The emergence of many new effective and interesting methods and approaches to learning a foreign language determines the needs of society, offering the student an individual approach depending on the required depth of their knowledge, needs, opportunities and time devoted to language learning.

From all of the above, it should be concluded that it is important for teachers to constantly improve their knowledge of foreign language teaching methods, introduce the latest educational concepts into their teaching practice, and be aware of the latest events.

\section{BIBLIOGRAPHY}

1. Альошина О. М. Сучасні методи та технології викладання іноземних мов у ВНЗ. Проблеми та перспективи формування національної гуманітарно-технічної еліти. 2012. № 30-31 (34-35). С. 242-247.

2. Артемьева О. А. Методология организации профессиональной подготовки специалиста на основе межкультурной коммуникации : монография. Тамбов : ТГТУ, 2005. 160 с.

3. Бабанский Ю. К. Методы обучения в современной общеобразовательной школе. Москва : Просвещение, 1985. $208 \mathrm{c.}$

4. Вятютнев М. Н. Теория учебника русского языка как иностранного (методические основы). Москва : Русский язык, 1984. 144 с.

5. Кашина Е. Г. Традиции и инновации в методике преподавания иностранного языка : учебное пособие. Самара : Изд-во Универс-групп, 2006. 75 с.

6. Кондрашова Л. В., Пермяков О. А., Зеленкова Н.І., Лаврешина Г.Ю. Педагогіка в запитаннях і відповідях : навч. посіб. Київ : Знання, 2006. 252 с.

7. Подласов С. О., Матвійчук О. В., Бригінець, В. П. Елементи змішаного навчання фізики в технічному університеті. Інформаційні технологї̈ $і$ засоби навчання. 2017. № 5, т. 61. С. 151-152.

8. Щеглова А. О. Місце проектного методу для формування і розвитку іншомовної комунікативної компетентності студентів в умовах змішаного навчання. Інформаційні технології і засоби навчання. 2016. № 3, т. 53. С. $142-149$.

\section{REFERENCES}

1. Aloshyna, O. M. (2012). Suchasni metodi ta tehnologii vikladannja inozemnih mov u VNZ [Modern methods and technologies of teaching foreign languages in universities]. Problemi ta perspektivi formuvannja nacional'noi gumanitarnotehnichnoi eliti. [Problems and prospects of formation of the national humanitarian and technical elite]. Kharkiv: NTU “KhPI”, № 30-31 (34-35). pp. 242-247 [in Ukrainian].

2. Artemeva, O. A. (2005). Metodologija organizacii professional'noj podgotovki specialista na osnove mezhkul'turnoj kommunikacii. [Methodology for organizing of specialist's professional training based on intercultural communication]. Tambov: TGTU, 160 p. [in Russian].

3. Babanskyi, Ju. K. (1985). Metody obuchenija v sovremennoj obshheobrazovatel'noj shkole. [Teaching methods in modern secondary school]. M. : Prosveshhenie, 208 p. [in Russian].

4. Viatiutnev, M. N. (1984). Teoriya uchebnika russkogo yazyka kak inostrannogo (metodicheskie osnovy). [Textbook theory of Russian as a foreign language (methodological foundations)] M. : Russkiy yazyk, 144 p. [in Russian].

5. Kashyna, E. G. (2006). Traditsii i innovatsii v metodike prepodavaniya inostrannogo yazyka. [Traditions and innovations in foreign language teaching methods]. Samara : Izd-vo «Univers-grupp», 75 p. [in Russian].

6. Kondrashova, L. V., Permiakov, O. A., Zelenkova, N. I., Lavreshyna, G. Yu. (2006). Pedahohika v zapytanniakh i vidpovidiakh. [Pedagogy in questions and answers]. K. : Znannia, 252 p. [in Ukrainian].

7. Podlasov, S., Matviichuk, O., Bryhinets, V. (2017). Elementy zmishanoho navchannia fizyky v tekhnichnomu universyteti. [Elements of blended learning in studying physics in the technical university]. Informatsiini tekhnolohii $i$ zasoby navchannia [Information Technologies and Learning Tools], vol. 61, no. 5, pp. 151-152 [in Ukrainian].

8. Shcheglova, O. (2016). Mistse proektnoho metodu dlia formuvannia i rozvytku inshomovnoi komunikatyvnoi kompetentnosti studentiv v umovakh zmishanoho navchannia. [The Importance of Project-Based Method for Formation and Improving of Foreign Communicative Competence in Blended Learning]. Informatsiini tekhnolohii $i$ zasoby navchannia [Information Technologies and Learning Tools], vol. 53, no. 3, pp. 142-149 [in Ukrainian]. 